\title{
Media and Power After Stuart Hall
}

\section{GERARD GOGgIN}

UNIVERSITY OF SYDNEY

In commemorating Stuart Hall, I wish to pay particular attention to the importance of his work for understanding one of the great topics of contemporary culturemedia.

There is a long discussion to be had of Stuart Hall's making and use of media, in various forms, from his early days of political activism, to television and film productions, videos and interviews. But his contribution to how we think about the media, to media theory and cultural theory of media, remains especially rich. What Hall has to teach us, and provoke us with, concerning media, is centrally about power.

A defining text of Hall on power and media is, of course, his aggregrative, evolving, famous paper on encoding and decoding. ${ }^{1}$ We still set this paper in our courses on media at the University of Sydney-at introductory and advanced terms of the Creative Commons Attribution 4.0 Unported (CC BY 4.0) License (https://creativecommons.org/licenses/by/4.0/), allowing third parties to copy and redistribute the material in any medium or format and to remix, transform, and build upon the material for any purpose, even commercially, provided the original work is properly cited and states its license. 
levels-as it condenses and presages various strands of intellectual debate about signs and means, texts, audiences and institutions.

In my intellectual formation, I came to this text very late-when I had to teach it-and, to be honest, before I read it, I couldn't see what all the fuss was about. It was a later, collaborative text of Hall's that I found much more striking and generative. I'm referring here to Policing the Crisis: Mugging, the State, and Law Order, the 1978 book Stuart Hall wrote with four co-authors. ${ }^{2}$

In 1999, I was finding my way into media studies, in my first academic post, at Southern Cross University, Lismore, when a controversy broke out occasioned by the broadening of the use of sniffer dogs in public places in New South Wales to find and interdict drug users. This was an especially big issue on the far north coast of New South Wales. Dubbed the 'Rainbow Region', this is where a particularly lively if politically riven public sphere amplified issues to do with lifestyle, pleasure and illicit substances. ${ }^{3}$ So my colleague Fiona Martin and I wrote a paper entitled 'Who Let the Dogs Out!', where we used the ideas in Policing the Crisis to theorise the peculiar close relations among government, law, social concerns and media in Northern Rivers. ${ }^{4}$ We did some fieldwork in Nimbin, and elsewhere, and our research culminated with a rowdy public forum in Lismore, where the regional police commander, a local National Party parliamentarian and the editor of the mainstream Northern Star daily newspaper argued it out with local social entrepreneurs, commentators and citizens of a wide range of political hues.

The concept of 'moral panic' elaborated in Policing the Crisis continues to be an important concept to at least refer to (or indicate) the irruption of a striking, almost inexplicable, outgrowth of an issue that constellates a range of institutions. Although the ensuing theoretical debates, and work on moral panic in the Australian context-the collection Outrageous!: Moral Panics in Australia, published after the 2005 Cronulla Riots, for instance-have underscored how the integrated, coordinated theoretical account given in Policing the Crisis is no longer adequate for understanding, and intervening in, the forms of power and media that obtain now. 5 Moreover it is no longer adequate for understanding how these work across the specificity of different cultures and societies, something I encountered when I wrote about 'mobile panics', or panics associated with mobile phones, in my book Cell Phone Culture. ${ }^{6}$ 
The second text of Hall's that has been particularly important to me, and I think to cultural accounts of media generally, especially in the Australian context, is the 1999 book Doing Cultural Studies: The Story of the Sony Walkman.7 Actually the lead author on this book was Paul du Gay; Hall was the second author, and it was cowritten with four other colleagues. It was also a widely used and admired textbook, influential for generations of cultural studies scholars. Doing Cultural Studies provides a rounded, integrated framework for acknowledging and attempting to bring together representation and identity with consumption, production and regulation (broadly conceived): the famous 'circuit of culture'. I used the 'circuit of culture' model as a broad starting point for my biography, as it was, of the mobile phone. What I like about Doing Cultural Studies, and it seems to be consistent with trends in what became to be called 'cultural research' in the ensuing decade or so, is the clear sense that analyses of cultural texts, media forms, technologies and affordances, and social identities, really do matter. Moreover, that the stuff of culture has intrinsic links to the realms of industry, economy, law and power and media institutions, as much as it does to everyday life.

So, what do the landscapes of power and media we now inhabit look like after Stuart Hall?

Well, technology certainly looms large in contemporary culture; and this wasn't something that Stuart Hall gave us specific analytic tools or ideas to handle, despite the Sony Walkman study in Doing Cultural Studies. So, it is no surprise that large swatches of contemporary cultural studies research (probably more than curriculum and pedagogy) is fascinated with actor-network-theory, Deleuzean theory, post-representational theories and what Jonathan Sterne has recently identified as the urge to find materialities pretty much everywhere. ${ }^{8}$ In various ways, the turn to theorise technology-intensive emergent media has headed off in different directions, predicated on breaking the mould of classic Hall-ean inspired cultural studies work.

Yet many of us traffic in these new conceptual terrains of media and culture but also continue to find compelling the clear, urgent drive to analyse and bring together the connected modes of power in and through media that Hall's own work, and that of his collaborators, evocatively exemplifies. 
Gerard Goggin is Professor of Media and Communications and ARC Future Fellow, University of Sydney.

\section{-NOTES}

1 Stuart Hall, Encoding and Decoding in the Television Discourse, stenciled occasional paper, Media Series, no. 7, Centre for Cultural Studies, University of Birmingham, 1973; Stuart Hall, 'Encoding/decoding', in Centre for Contemporary Cultural Studies (ed.), Culture, Media, Language: Working Papers in Cultural Studies, 1972-79, Hutchinson, London, 1980, pp. 128-38.

2 Stuart Hall, Chas Critcher, Tony Jefferson, John Clarke and Brian Roberts, Policing the Crisis: Mugging, the State, and Law and Order, Macmillan, London, 1970.

${ }^{3}$ Helen Wilson (ed.), Belonging in the Rainbow Region: Cultural Perspectives on the NSW North Coast, Southern Cross University Press, Lismore, NSW, 2003.

4 Gerard Goggin and Fiona Martin, “'Who Let the Dogs Out?": Drugs, Media and Policing in Northern NSW', paper delivered to Australian and New Zealand Communications Association (ANZCA)

Transdisciplinarity conference, Perth, 1-3 July 2001.

5 Scott Poynting and George Morgan (eds), Outrageous!: Moral Panics in Australia, ACYS Publishing, Hobart, 2007.

6 Gerard Goggin, Cell Phone Culture: Mobile Technology in Everyday Life, Routledge, London and New York, 2006.

7 Paul du Gay, Stuart Hall, Linda Janes, Hugh Mackay and Keith Negus, Doing Cultural Studies: The Story of the Sony Walkman, Sage and Open University Press, London and Thousand Oaks, CA, 1997.

${ }^{8}$ Jonathan Sterne, “'What Do We Want?" “Materiality!" “When Do We Want It?” "Now!'” in Tarleton Gillespie, Kirsten Foote and Pablo Boczkowski (eds), Media Technologies: Essays on Communication, Materiality and Society, MIT Press, Cambridge, MA, 2014, pp. 119-28.

\section{-BIBLIOGRAPHY}

du Gay, P., S. Hall, L. Janes, H. Mackay and K. Negus, Doing Cultural Studies: The Story of the Sony Walkman, Sage and Open University Press, London and Thousand Oaks, CA, 1997.

Goggin, G., Cell Phone Culture: Mobile Technology in Everyday Life, Routledge, London and New York, 2006.

Goggin, G. and F. Martin, ' “Who Let the Dogs Out?”: Drugs, Media and Policing in Northern NSW', paper delivered to Australian and New Zealand Communications Association (ANZCA) Transdisciplinarity conference, Perth, 1-3 July 2001. 
Hall, S., C. Critcher, T. Jefferson, J. Clarke and B. Roberts, Policing the Crisis: Mugging, the State, and Law and Order, Macmillan, London, 1970.

Poynting, S. and G. Morgan (eds), Outrageous!: Moral Panics in Australia, ACYS Publishing, Hobart, Tasmania, 2007.

Sterne, J., “'What Do We Want?” “Materiality!” “When Do We Want It?” “Now!"' in T. Gillespie, K. Foote and P. Boczkowski (eds), Media Technologies: Essays on Communication, Materiality and Society, MIT Press, Cambridge, MA, 2014. doi: http://dx.doi.org/10.7551/mitpress/9780262525374.003.0006

Wilson, H. (ed.), Belonging in the Rainbow Region: Cultural Perspectives on the NSW North Coast, Southern Cross University Press, Lismore, NSW, 2003. 